\title{
遺伝子発現変化を伴わない潜在的分子メカニズムーエピジェネテイック・プライミングー による植物再生
}

\author{
松永幸大 \\ 東京大学大学院新領域創成科学研究科先端生命科学専攻
}

要旨：エピジェネティック・プライミングは遺伝子発現変化を伴わずに，遺伝子発現前の待機状態赵創り出す潜在 的な分子メカニズムである. ヌクレオソームを解きクロマチンをオープンな状態にすることで将来の遺伝子発現に 備える状態を創り出す。エピジェネティック・プライミングは, 幹細胞の分化や細胞のガン化の前段階や薬物中毒 の進行段階に見られるが，植物再分化への関与の報告はなかった．今回，私達はシロイヌナズナの変異体スクリー ニングによって，植物のエピジェネティク・プライミング因子として，ヒストン脱メチル化酵素LYSINE-SPECIFIC DEMETHYLASE 1-LIKE 3(LDL3) t同定した。 カルス形成中に, LDL3はH3K4me2 t取り除くことで, 将来のシュー 卜誘導に備えてシュート形成遺伝子群支遺伝子発現の待機状態にする. 今回の研究から, 植物の再生力を支える分子 機構に，エピジェネティック・プライミングが関与することがわかった.

\section{Plant regeneration by epigenetic priming}

\section{Sachihiro Matsunaga}

Department of Integrated Biosciences, Graduate School of Frontier Sciences, The University of Tokyo, 5-1-5 Kashiwanoha, Kashiwa, Chiba 277-8562, Japan

Author for correspondence: S. Matsunaga, sachi@edu.k.u-tokyo.ac.jp

Summary: Epigenetic priming is one of the potential systems that genes are poised for activation by external signal inputs. Although the priming does not alter the gene expression, it is considered to induce the open structure of chromatin and the poised state for the future transcription. This priming is involved in stem cell differentiation, cancer development and drug action but remains unclear in plant regeneration. Through integrated analysis of genome-wide histone modifications and gene expression profiles, we successfully identified an epigenetic priming by a histone demethylase LYSINE-SPECIFIC DEMETHYLASE 1-LIKE 3 (LDL3) that specifically eliminates H3K4me2 during formation of callus derived from roots of Arabidopsis thaliana. While LDL3-mediated H3K4me2 removal does not immediately affect gene expression, it does facilitate the later activation of genes that act to form shoot progenitors after shoot induction. This finding gives insights into plant regenerative competency with epigenetic priming.

Key words: epigenetic priming, histone demethylation, histone modification, plant regeneration, shoot regeneration

はじめに

エピジェネティクスは「DNA塩基配列自体の変化を伴 わず，細胞分裂後も継承される核内変化」と捉えることが できる。この約 30 年の DNA 修飾・ヒストン修飾・クロマ チン構造変化・核内三次元構造などのエピジェネティクス 研究により，DNAからタンパク質への「一方通行の流れ」 を表したセントラルドクマは，多様で柔軟性のある「遺伝 情報と表現型の双方向性」在表す分子システムへと変貌を 遂げた。

エピジェネテイクスにより，獲得形質の世代を超えた継 承例が見つかるとともに，ゲノム的には全く同一な一卵性 双生児の性格や健康状態の違いなぞ, 従来の遺伝学では説 明できない現象が説明できるようになりつつある。中でも 遺伝子発現の分子メカニズム解明に, エピジェネティクス の概念が導入されることで, 研究手法そのものが大きく変 わつてきた。

従来研究では, 環境刺激や分化誘導により, 表現型に 大きく変化が起こつた時に, その前後で遺伝子発現を比 較してきた，例えば，変化前と変化後の細胞・組織・器
官を集めてきて mRNAを抽出しライブラリーを構築し て, RNA-seqにかけて upregulation (発現が上昇した) や downregulation (発現が減少した) 遺伝子群を比較解析する 手法である。しかし，生命現象の解明には時間軸を考慮す ることが重要である，例えば, 変化後の状態と比較する「変 化前」という状態は，1分前・1時間前・1日前・1週間前で も異なる。また，生物は将来を予測して，プログラミング された遺伝子発現に従って, 成長・分化していく場合もあ る。生物は周囲の環境から，絶えず刺激と影響を受け続け ており，その反応は表現型として現れずとも，潜在的に生 体内で蓄積されている可能性が高い.

この表現型が現れない, つまり遺伝子発現を伴なわない, 細胞核内で起こる潜在的分子メカニズムが「エピジェネテ イック・プライミング」である。

最初の報告は，様々な血球系細胞に分化する造血幹細 胞 (hematopoietic stem cell) の研究によってもたらされた. 造血幹細胞から赤血球系造血細胞 (erythroid cell) に分化す るときに, $\beta$ グロブリン遺伝子の急激な発現上昇がみられる. ところが，その分化前 (遺伝子発現上昇前)の造血幹細胞 
の時から, $\beta$ グロブリン遺伝子座のクロマチン内に, 遺伝 子発現が上昇するときに見られるヒストン修飾が検出され た.このヒストン修飾は, ヌクレオンームを解きDNAを 露出させ, クロマチンを構造的に開くとともに, その場所 にRNAポリメラーゼII を呼び込むための土台となる基本 転写因子群を結合させている。つまり, あらかじめ将来の 遺伝子発現に備えて, 特定の遺伝子座のヒストンが修飾さ れることが報告されたのである。

この遺伝子発現前のヒストン修飾変化の報告以前には, 分化前のマクロファージ系前駆細胞や神経前駆細胞におい て, 分化後に働くマクロファージや神経特異的な遺伝子群 の上流転写制御領域に基本転写因子群があらかじめ結合す ることが報告されていた (Kontaraki et al. 2000, Leferve et al. 2003). 従来, 基本転写因子群は, 遺伝子発現のための 刺激や分化スイッチ後に, 特定遺伝子群の上流域に結合す ると考えられていたが, 一部の遺伝子の上流域には基本転 写因子群が分化刺激前からあらかじめ結合して待機状態を 創る可能性が示唆されていたのである.

その後, このような分化刺激前からあらかじめヒストン 修飾変化により遺伝子発現の待機状態を創り出すことを「エ ピジェネティク・プライミング」と呼ぶようになり, 血球 の分化 (Waleter et al. 2008), ヒト幹細胞の分化 (Spivakov and Fisher 2007, Liber et al. 2010, Dillon 2012), ヒトの胚 発生 (Wang et al. 2015), ガン化 (Vicente-Duenas et al. 2018), 薬物中毒発症 (五十嵐 2017, Mews et al. 2018) なぞ, 様々な現象に関与する分子機構として知られるようになつ た、今回，私達はエピジェネティク・プライミングによ つて植物再生が制御されることを見出した (Ishihara et al. 2019).

\section{エピジェネティクス因子LDL3 の同定とイメージング解析}

植物のシュート再分化現象におけるエピジェネティク制 御機構に興味を持ち, シロイヌナズナのヒストン修飾酵素
の変異体を用いて分子機構の解明を試みた. シロイヌナズ ナの根をカルス誘導培地に置いて 14 日間カルスを誘導し た後, シュート誘導培地に移してシュートを再分化させる システムを用いた. このシステムを用いてヒストン修飾変 異体をスクリーニングした. その結果, カルスは正常に形 成されるが, シュート誘導培地に移して 21 日経過した後 でもシュートの再分化が起こらない変異体として, ヒスト ン脱メチル化酵素LDL3 (Lysine-specific Demethylase Like 3)の変異体 $l d l 3$ を同定した (Ishihara et al. 2019) (図 1).

ヒストン脱メチル化酵素はヒストンのメチル化リシン残 基を脱メチル化する反応を触媒する。真核生物のヒストン メチル化酵素は, フラビン依存性のモノアミン酸化酵素 であるLSD ファミリー(Shi et al. 2004), jumonji domain を持つJMJファミリー (Takeuchi et al. 1995, Yamane et al. 2006)の二つに大別される (Shi and Tsukada 2013). LDL3 は前者のLSD ファミリーに属している．ヒトのLSDファ ミリーに属するLSD1 は, ガン化の引き金因子として解析 が進んでおり, LSD1 をターゲットとした制癌剤の開発が 盛んに行われている (Ota and Suzuki 2018).

シロイヌナズナのLSDファミリーにはLDL1, LDL2, LDL3, FLD (Flowering Locus D) の4つのパラログがある. これらの変異体はいずれも早咲き (early flowering)の表 現型を示す (Martignago et al. 2019). また, LDL2は遺伝 子内部 (gene body) の H3K4me1 を減少させることで, 転 写抑制を引き起こすことが報告されている (Inagaki et al. 2018). ld ll , ldl2, fld 変異体は, シュート再生に異常がみら れないことから, LSD ファミリー中, シュート再生に関与 する因子はLDL3のみであることがわかった.

LDL3の植物脱分化過程および再分化過程における発現 パターンを解析した. LDL3 プロモーター下にLDL3-GFP を繋いだ pLDL3::LDL3-GFPベクターをldl3変異体に導入 し, 二光子顕微鏡によるディープイメージングを行った (図2).その結果, 根では維管束周辺の内鞘細胞 (pericycle
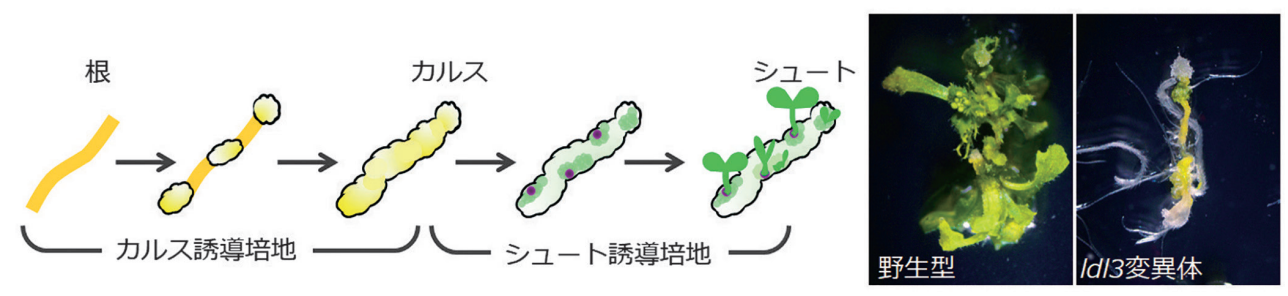

図 1 カルス形成とシュート再 生のシステムとldl3変異体の表 現型. 右写真はシュート誘導培 地21日目のカルスを示す。

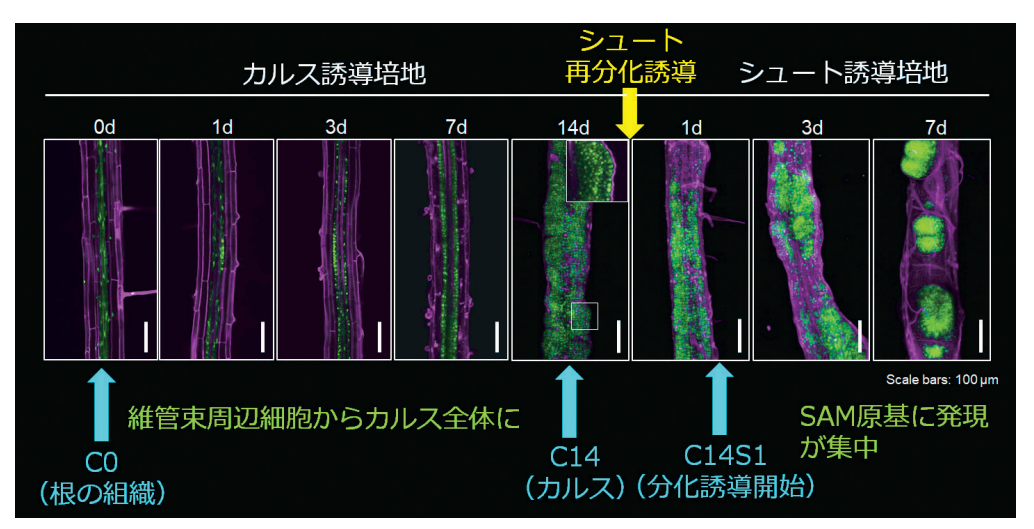

図2 二光子顕微鏡によるLDL3発現のディープイ メージング解析。根 $(0 \mathrm{~d})$ からカルス誘導培地 14 日目 (14d)のカルス, シュート誘導培地 1 日目 (1d) から 7 日目 (7d)のカルスを解析した. マジェンダはPI染色, 緑はGFP蛍光を示す。14d の右上に右下白線内の拡 大図在示守。 
cells)でLDL3 は主に発現していた. カルス誘導培地上の 根由来のカルスでは, LDL3の発現パターンは徐々に広が り, カルス誘導培地 14 日目では, カルス全体にその発現 が見られた。 また，カルス誘導培地から移植したシュート 誘導培地 7 日目のカルスには, シュートが生じる茥頂分裂 組織 (SAM) 原基でLDL3の発現が多く検出された.このよ うなカルス全体からSAM原基に集中する発現パターンから, LDL3がシュート再生に関与することを裏付けることがで きた。

\section{LDL3 はカルスにおける根端分裂組織の遺伝子群の発現減少 には関与しない}

組織や器官は細胞分裂によって構築される。細胞分裂し ても，分化を裏打ちする遺伝子発現の特異性が失われない ことから, 組織や器官の特異性も失われることはない。 こ のような遺伝子発現の継承のことを細胞記憶と呼ぶ(田中, 2011)。また，iPS細胞は，それが由来する細胞の遺伝子発 現情報をエピジェネティクスとして温存している。そのた め, 由来する細胞に分化する効率が非由来細胞に分化する 効率よりも高い (Hu et al. 2010, Kim et al. 2010). このよ うに細胞が遺伝子発現情報をエピジェネティクスとして細 胞記憶することをエピジェネテイク記憶と呼ぶ. iPS 細胞 を継代培養すると, 由来する元の細胞のエピジェネティク 記憶は消去される (Luu et al. 2018).

根から脱分化して形成されたカルスは，根の細胞記憶を 維持している。 また, 由来がぞのような器官であってもカ ルスは, 根端分裂組織の遺伝子発現を維持していることが 知られている (Sugimoto et al. 2010, Sugimoto et al. 2011). カルスからシュートが再分化するときに，根端分裂組織の 遺伝子群の発現が減少し, SAMの遺伝子群の発現が上昇 することで, SAM原基が形成される．ld l3 変異体のカルス でSAM原基が形成されない理由として, 根端分裂組織の 遺伝子発現減少が起こらない, SAM形成に関与する遺伝 子の発現が上昇しない, さらにはその両方がうまくいかな いことが考えられた。

そこで, カルス誘導培地 14 日目のカルス (シュート誘 導培地に移す直前のカルス), シュート誘導培地に移して 1日目と7日目のカルスにおける遺伝子発現を, 野生型々 $l d l 3$ 变異体で比較解析した. その結果, 根端分裂組織の遺 伝子群の発現抑制には差はなかった。このことは, ld l 3 変 異体においても根の細胞記憶消去は起こっていることを示
しており, LDL3が根端分裂組織の遺伝子群の発現減少に 関与していないことがわかった。一方，シュート誘導培 地移行後1日目および7日目の野生型のカルスでは, SAM の形成に関与する遺伝子群の発現上昇がみられるが, $\quad l d l 3$ 変異体のカルスでは発現上昇が見られなかった。つまり, ld l 3 変異体で SAM 原基が形成されない理由は, シュート 誘導培地に移植してもSAM遺伝子群の遺伝子発現が上昇 しないからである。

\section{LDL3によるヒストン脱メチル化によってエピジェネティク・プ ライミングが起きる}

次に, クロマチン免疫沈降を用いて, 根, カルス誘導地 14 日目のカルス, シュート誘導培地に移してから 1 日目の カルスでヒストン H3K4meの状態を比較した。野生型と ld l3 変異体の間で, $\mathrm{H} 3, \mathrm{H} 3 \mathrm{~K} 4 \mathrm{me} 1, \mathrm{H} 3 \mathrm{~K} 4 \mathrm{me} 3$ の差はなか つたが, H3K4me2 はldl3変異型カルス特異的に蓄積して いた。驚いたことに，その $\mathrm{H} 3 \mathrm{~K} 4 \mathrm{me} 2$ 蓄積パターンは，力 ルス誘導地 14 日目のカルスとシュート誘導培地に移して から1日目のカルスの間で, ほとんど同じであった(図3). つまり, H3K4me2のヒストン修飾は, カルス誘導培地か らシュート誘導培地に移植しても変化しなかったのである. これは，シュート培地に移行する前のカルスの段階から， LDL3 はH HK4me2 取り除いており, 分化誘導が起こつ てから取り除くわけではないことを意味している(図4). つまり, LDL3 はカルスの段階から H3K4me2 脱メチル

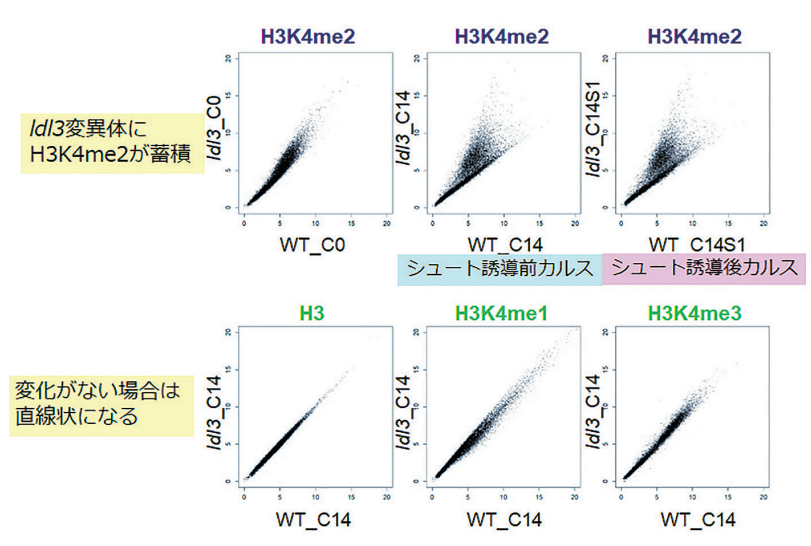

図3クロマチン免疫沈降による野生型と $l d l 3$ 変異体の H3K4meの 比較.
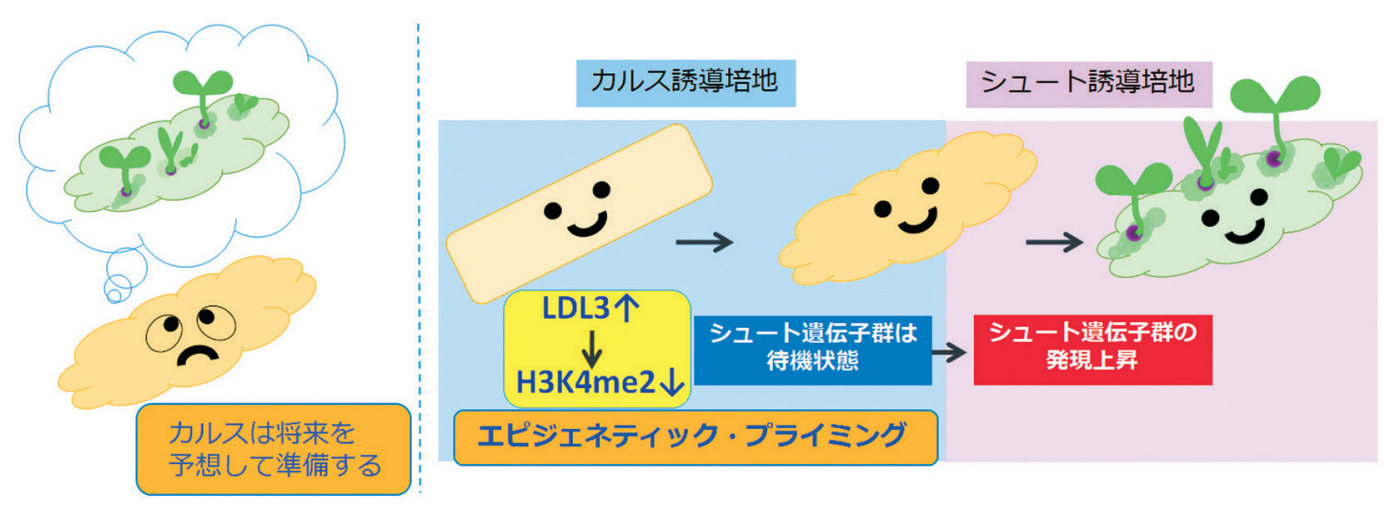

図 4 LDL3 による シュート形成遺伝 子群のエピジエネ ティック・プライミ ング. 
化し，シュート誘導に備えて遺伝子発現の待機状態を創り

出すエピジェネティック・プライミング因子であった．

そこで, カルス中に起こる H3K4me2の減少が起こる遺 伝子座を同定したところ, シュート形成に関わる既知の遺 伝子群の他に, シュート再生への関与が未報告のハウスキ ーピング遺伝子がみつかつた，それらの遺伝子は, アンモ 二ウム代謝酵素, ユビキン化タンパク質, グルタミン酸合 成酵素などをコードしていた。 それらの变異体を用いて, シュート再生の表現型を調べた。その結果, この表現型は $l d l 3$ 変異体に比較して弱い表現型であつたが, いずれの変 異体もシュート再生の頻度が低くなった. このことは, 従 来の分化誘導刺激前後の比較発現解析では見出せない分化 に関与するハウスキーピング遺伝子群も, エピジェネティ ク・プライミングを指標に同定できることも示している.

私達が発見したLDL3による H3K4me2の除去を基盤と したエピジェネティック・プライミングは, 動植物を通じ て初めて「ヒストン修飾のイレイサー」がプライミングに 関与することを示した報告となった，今後, LDL3 と相互 作用する因子局定し，植物再生のエピジェネティクス・ プライミング複合体の解析を進めていきたいと考えている.

\section{おわりに}

エピジェネティック・プライミングの研究は開始され たばかりである。動物細胞の分化遺伝子のエンハンサー は, 遺伝子発現前にオープンクロマチンの状態になり, H3K4me1 修飾されて, エンハンサーRNAが転写される (Suzuki et al. 2017). この一連の過程は, エピジェネティ ック・モジュレーションと呼ばれるが, プライミングやパ イオ二ア転写因子との関係は不明なままである。転写開始 のための基本転写因子群や RNA ポリメラーゼのリン酸化 との関係など, 遺伝子発現待機状態を創り出すエピジェネ テイック・プライミングは, 更にその分子メカニズムの研 究が必要である. 遺伝子発現の前に起こる潜在的なメカ二 ズムによって生命現象を新しい側面から説明できるように なることを期待したい.

\section{謝辞}

本研究は, 石原弘也氏, 杉本薰博士, 稲垣宗一博士, 乾 弥生博士, 坂本卓也博士, 鈴木孝征博士, 関原明教授, 角 谷徹仁教授, ポール・ター博士, エリオット・マイロビッ ツ教授との共同研究成果である. 科研費 $19 \mathrm{H} 03259$ および 15H05962の支援を受けた. Figureはすべてクリエイテイブ・ コモンズ・ライセンス (表示 4.0 国際) のもとに改変して作 成した. https://creativecommons.org/licenses/by/4.0/

\section{引用文献}

Bottardi, S., Aumont, A., Grosveld, F., and Milot, E. (2003) Developmental stage-specific epigenetic control of human $\beta$-globin gene expression is potentiated in hematopoietic progenitor cells prior to their transcriptional activation. Blood 102: 3989-3997.

Dillon, N. (2012) Factor mediated gene priming in pluripotent stem cells sets the stage for lineage specification. Bioessays 34: 194-204.

Hu, Q., Friedrich, A. M., Johnson, L. V., and Clegg, D. O. (2010)
Memory in induced pluripotent stem cells: reprogrammed human retinal-pigmented epithelial cells show tendency for spontaneous redifferentiation. Stem Cells 28: 1981-1991.

Inagaki, S., Takahashi, M., Hosaka, A., Ito, T., Toyoda, A., Fujiyama, A., Tarutani, Y., and Kakutani, T. (2017) Gene-body chromatin modification dynamics mediate epigenome differentiation in Arabidopsis. EMBO J 36: 970980.

Ishihara, H., Sugimoto, K., Tarr, P. T., Temman, H., Kadokura, S., Inui, Y., Sakamoto, T., Sasaki, T., Aida, M., Suzuki, T., Inagaki, S., Morohashi, K., Seki, M., Kakutani, T., Meyerowitz, E. M., and Matsunaga, S. (2019) Primed histone demethylation regulates shoot regenerative competency. Nat Commun 10: 1786.

Kim, K., Doi, A., Wen, B., Ng, K., Zhao, R., Cahan, P., Kim, J., Aryee, M. J., Ji, H., Ehrlich, L. I., Yabuuchi, A., Takeuchi, A., Cunniff, K. C., Hongguang, H., McKinney-Freeman, S., Naveiras, O., Yoon, T. J., Irizarry, R. A., Jung, N., Seita, J., Hanna, J., Murakami, P., Jaenisch, R., Weissleder, R., Orkin, S. H., Weissman, I. L., Feinberg, A. P., and Daley, G. Q. (2010) Epigenetic memory in induced pluripotent stem cells. Nature 467: 285-290.

Kontaraki, J., Chen, H. H., Riggs, A., and Bonifer, C. (2000) Chromatin fine structure profiles for a developmentally regulated gene: reorganization of the lysozyme locus before trans-activator binding and gene expression. Genes Dev 14: 2106-2122.

Lefevre, P., Melnik, S., Wilson, N., Riggs, A. D., and Bonifer, C. (2003) Developmentally regulated recruitment of transcription factors and chromatin modification activities to chicken lysozyme cis-regulatory elements in vivo. Mol Cell Biol 23: 4386-4400.

Liber, D., Domaschenz, R., Holmqvist, P. H., Mazzarella, L., Georgiou, A., Leleu, M., Fisher, A. G., Labosky, P. A., and Dillon, N. (2010) Epigenetic priming of a pre-B cell-specific enhancer through binding of Sox 2 and Foxd3 at the ESC stage. Cell Stem Cell 7: 114-126.

Luu, P. L., Gerovska, D., Schöler, H. R., and Araúzo-Bravo, M. J. (2018) Rules governing the mechanism of epigenetic reprogramming memory. Epigenomics 10: 149-174.

Martignago, D., Bernardini, B., Polticelli, F., Salvi, D., Cona, A., Angelini, R., and Tavladoraki, P. (2019) The four FAD-dependent histone demethylases of Arabidopsis are differently involved in the control of flowering time. Front. Plant Sci. 10: 669.

Mews, P., Walker, D. M., and Nestler, E. J. (2018) Epigenetic priming in drug addiction. Cold Spring Harb Symp Quant Biol 83:131-139.

Ota, Y., and Suzuki, T. (2018) Drug design concepts for LSD1selective inhibitors. Chem Rec 18: 1782-1791.

Shi, Y. G., and Tsukada, Y. (2013) The discovery of histone demethylases. Cold Spring Harb Perspect Biol 5: a017947.

Shi, Y., Lan, F., Matson, C., Mulligan, P., Whetstine, J.R., Cole, P. A., Casero, R. A., and Shi, Y. (2004) Histone demethylation mediated by the nuclear amine oxidase 
homolog LSD1. Cell 119: 941-953

Spivakov, M. and Fisher, A. G. (2007) Epigenetic signatures of stem-cell identity. Nat Rev Genet 8: 263-271.

Sugimoto, K., Gordon, S. P., and Meyerowitz, E. M. (2011) Regeneration in plants and animals: dedifferentiation, transdifferentiation, or just differentiation? Trends Cell Biol 21: 212-218.

Sugimoto, K., Jiao, Y., and Meyerowitz, E. M. (2010) Arabidopsis regeneration from multiple tissues occurs via a root development pathway. Dev Cell 18: 463-471.

Suzuki, H. I., Young, R. A., and Sharp, P. A. (2017) Superenhancer-mediated RNA processing revealed by integrative microRNA network analysis. Cell 168: 1000-1014.

Takeuchi, T., Yamazaki, Y., Katoh-Fukui, Y., Tsuchiya, R., Kondo, S., Motoyama, J., and Higashinakagawa, T. (1995) Gene trap capture of a novel mouse gene, jumonji, required for neural tube formation. Genes Dev 9: 1211-1222.

Vicente-Dueñas, C., Hauer, J., Cobaleda, C., Borkhardt, A., and Sánchez-García, I. (2018) Epigenetic priming in cancer initiation. Trends Cancer 4: 408-417.

Walter, K., Bonifer. C., and Tagoh, H. (2008) Stem cell-specific epigenetic priming and $\mathrm{B}$ cell-specific transcriptional activation at the mouse Cd19 locus. Blood 112: 1673-1682.

Wang, A., Yue, F., Li, Y., Xie, R., Harper, T., Patel, N. A., Muth, K., Palmer, J., Qiu, Y., Wang, J., Lam, D. K., Raum, J. C., Stoffers, D. A., Ren, B., and Sander, M. (2015) Epigenetic priming of enhancers predicts developmental competence of hESC-derived endodermal lineage intermediates. Cell Stem Cell 16: 386-399.

Yamane, K., Toumazou, C., Tsukada, Y., Erdjument-Bromage, H., Tempst, P., Wong, J., and Zhang, Y. (2006) JHDM2A, a JmjC-containing $\mathrm{H} 3 \mathrm{~K} 9$ demethylase, facilitates transcription activation by androgen receptor. Cell 125: 483-495.

五十嵐勝秀, 大塚 (出田) まき, 成田年 (2017) エピジェネ ティック毒性研究の現状と今後の展開 薬学雑誌 137 : 265-271.

田中知明 (2011)「細胞の記憶」, エピジェネティクスと疾 患〜細胞と個体, 複雑なシグナルとエピジェネティク ス走結びつける「生老病死」の分子生物学〜。日老医誌 48, 305-311.

Received: 15 January 2020 / Accepted: 9 March 2020 